\title{
To The Question of the Right of Indigenous Peoples to Self-Determination and Its Interpretation in International Law
}

\author{
Fyodor I. Nikitin, Lenara R. Klimovskaya, Lenaris H. Mingazov
}

\begin{abstract}
It is well known that the right of indigenous peoples to self-determination today, as well as in the past, continues to be one of the most complex and difficult to solve issues for both national and international law as a whole. It certainly arouses great interest in itself and attracts attention from a wide circle of the public, excites the minds, and at the same time engenders the broadest discussions. Those discussions often provoke an aggravation of the already not benevolent relationship between indigenous peoples and government officials in their countries of residence. Along with this, those relationships continue to be defined and considered by most indigenous peoples of the world as the "foundation" on which their rights rest, as well as their survival and preservation as separate and independent peoples. Given this circumstance, the team of authors of this paper made an attempt to consider this controversial issue from a somewhat alternative point of view in relation to traditional concepts of self-determination of peoples, namely, from the standpoint of human rights and development policy. Thus, the authors bring a new interpretation to the discussion and study of this issue, which needs to be specified and defined.
\end{abstract}

Key words: indigenous peoples; human rights, the right of peoples to self-determination; development policy.

\section{INTRODUCTION}

With the development of human society and its institutions, there was also the formation of ideas about the rights of individuals and their groups. These include the idea of the right of peoples to self-determination, which is now one of the key principles of modern international law. So, historically, the right of peoples to self-determination has always been associated with the right to secession and the formation of a national state. Nevertheless, as the modern international regulatory system developed, some changes in its content took place, in particular, due to the emergence of key international documents, namely, the UN Charter, Human Rights Covenants, and also various declarations adopted by the UN General Assembly. However, until very recently, the latter declaration failed to find a completely consistent application, often continuing to be interpreted by states, similarly to as it was in the old days, to please their interests. The latter is also joined by an ambiguous interpretation of this provision in relation to indigenous peoples, which continue, until very recently, to be considered by many scholars as "dependent nations" [1, p. 25] being in the "internal colonial situation" [2, p.118].

Revised Manuscript Received on November 08, 2019.

* Correspondence Author

Fyodor I. Nikitin, Kazan Federal University

Lenara R. Klimovskaya, Kazan Federal University

Lenaris H. Mingazov, Kazan Federal University
In accordance with this, we intend to consider the issue of self-determination by indigenous peoples mainly from several sides: firstly, by examining the content of key international acts enshrining this right, and secondly, by paying attention to the existing practice of interpreting this right.

It is in this vein that we see an interpretation of the issue stated above, and therefore its study will be a particularly important task for us in this paper.

\section{METHODS}

When conducting the study, we used general scientific and special scientific methods of cognition, including system-structural, problem-theoretical, formal-legal, historical-legal, comparative-legal, logical, etc.

\section{RESULTS AND DISCUSSION}

As we know, the main international document that secured the right to self-determination for indigenous peoples is the UN Declaration on the Rights of Indigenous Peoples adopted in 2007 [3]. This act recognized that indigenous peoples have the right to self-determination, by virtue of which they freely establish their political status and freely carry out their economic, social and cultural development [3, Art.3]. Also, the possibility of using various forms of autonomy and self-government [3, Art.4] is defined as a form of exercising this right. Despite this, and upon the complexity of the conditions, this document failed to give an explanation of what the wording on "free establishment of political status and implementation of economic, social and cultural development" implies, and how the latter may be related to the provision of autonomy and self-government. This, in turn, predetermined the emergence of a discussion about the possibility of existence in relation to indigenous peoples also another form of self-determination, namely secession, or the right to secession and formation of an independent state.

In this regard, it seems to us possible to note that in the international legal literature a dichotomous structure of interpretation the right of peoples to self-determination has developed for a long time, and that is based on the "external" and "internal" aspects. However, in spite of this, it would probably be foolish to simply believe that such a complex phenomenon as the self-determination of peoples is reduced solely to independence and self-government. In accordance with this, we note that this doctrinal structure of interpretation the right of peoples to self-determination has long exhausted its positive impact on the development of peoples, and, on the contrary, has become a kind of rudiment that restrains 
the true development of both this right and the whole concept of the right to self-determination in general.

As for the issue of the implementation of this right by indigenous peoples, with any possible references on their part to the need to expand their self-government and grant them more sovereignty in the field of decision-making, the latter seems to be very difficult and somewhat impossible. The main reason here is the preservation of centuries-old antagonism of states that are often not interested in these changes, but, on the contrary, fear them.

So, the demands made by the natives are mainly reduced to the prohibition of their discrimination; protecting their rights as minorities; recognition of their historical sovereignty; and finally, recognition and fulfilment by states of the terms of treaties and agreements concluded in the past with their communities [4, p.69]. These requirements are increasingly provoking a wary and sometimes very negative reaction, as they are often identified by states with demands for independence and secession [5, p.343]. This, in principle, is an unconvincing argument, since for the most part many internationally active indigenous peoples and their representatives do not have goals for the secession or dismemberment of existing states, but only want to "continue to exist as separate communities free from oppression" [6, p.48].

Despite this, statements about the need for separation and independence are still sporadically heard from some Indian tribes of the USA and Canada [7, p. 180], the Innu of Greenland [8, p. 65-66], as well as some other indigenous peoples. These cases are isolated examples, and in principle, they cannot reflect the real picture, however, oddly enough, they continue to be used by states that similarly argue their unwillingness to consider the proposals and appeals of indigenous peoples.

The existing misconception about the perception by indigenous peoples of their right to self-determination is often based on a decolonization regime which has lost its relevance to date due to the fact that most colonial dependent peoples gained independence in the 60-70s of the last century. Thus, it seems to us that the applicability of this concept to indigenous peoples now seems unrealizable for a number of reasons, one of which is the prevailing tendency to prioritize the integrity and inviolability of state borders, which was also formulated in the middle of the 20th century [7, p.165]. From this, the following statement logically follows: "In the case of indigenous peoples, [their right to self-determination] cannot in any way assume automatic separation or the creation of their own national state," which both the domestic and foreign doctrine of international rights continues to insist [10, p.55].

In this regard, we afford us an opportunity to note that the consideration of the right of indigenous peoples, as well as, in fact, of other peoples, to self-determination at the present time should not be considered from the standpoint of separation or self-government, but from the point of view of human rights and development policies formulated in the past by famous American scientist, professor James S. Anaya.

Based on his judgment, the principle of self-determination is "laid down" in the human rights framework of modern international law and includes many human rights provisions that are applied to bring "benefit to all people" [12, p.9]. In accordance with it, the right of peoples to self-determination should not be considered as "internal" or "external", but as "substantive" and "corrective". The first of them requires that the "existing socio-political institutional order", in fact, be "an expression of the will and consciousness of people or nations", but also that it "provides them with a dignified life and free development on an on-going basis" [11, p. 9-10]. The second implies the necessary legal remedies aimed at eliminating the facts of historical violations and injustices associated with their right to self-determination, which, however, "should not necessarily entail a return to the territorial status quo" understood in historical aspect [11, p.18].

In relation to indigenous peoples, this approach can be applied in its "correctional aspect", since, like other peoples, they are the beneficiaries of the right to self-determination and were subject to the colonial regime, and that is, they became "victims of the "substantive element" of the right to self-determination [11, p.13].

In this regard, we are inclined to believe that the world community is obliged to respond more rapidly to more and more common cases when the rights of indigenous peoples became violated, making every possible effort to correct the situation. This, of course, must be consistent with what the natives themselves agree with, expressed by them through their national institutions of government that exist within the states in which they reside.

Our argument also found support and interpretation on the part of the UN Working Group on Indigenous Peoples, represented by the former Chairperson-Rapporteur, Professor Erica-Irene Daes, who characterized indigenous peoples' right to self-determination through the concept of "state-building". In her words, the latter was expressed in "the unification of indigenous peoples with all other peoples that make up the state" on the basis of "mutually agreed and fair conditions" [12, p.1,9].

In this regard, let us reiterate that the only element that should be addressed for interpretation the right of indigenous peoples to self-determination in accordance with the Declaration is the establishment by indigenous peoples of "autonomy or self-government" as possible conditions for the exercise of their right to self-determination. This is, in particular, stated in Article 4 of the Declaration which establishes that: "In the exercise of their right to self-determination, indigenous peoples have the right to autonomy or self-government in matters relating to their internal and local affairs, as well as ways and means of financing their autonomous functions." [3].

However, despite the allocation for indigenous peoples of these regimes within which those people can act, exercising their right to self-determination, the institution of autonomy of indigenous peoples should be understood mainly as an element of building the relations with the state and its institutions [13, p. 27-29].

Thus, it can be noted that the fundamental principle underlying the Declaration, of course, is the right of indigenous peoples to preserve and strengthen their distinctive features and legal systems, while maintaining the right to participate fully in the life of the state [3, Art.4, 8, 12-14, 19-21, 23]. It follows that the consideration and vision of this issue in the form of state-legal construction, in our opinion, will indeed contribute, at least in part, to the achievement of the possible development of these peoples, and will also allow for a more substantial restoration of the 
conditions and dynamics of their mutual relations with states and their governments.

\section{SUMMARY}

We summarize all of the above. It seems to us that the most acceptable approach to the issue of self-determination of indigenous peoples will be an approach aimed at building sustainable relations between indigenous peoples and the authorities of their states of residence. The reason is that this principle is recognized as fundamental for a deeper interpretation of the process of self-determination by indigenous peoples, and thus constitutes the normative basis for development policy [14, p.88].

In support of this argument, we point out that in paragraph 5, part I of the Vienna Declaration and in the Program of Action adopted on June 25, 1993, by the UN World Conference on Human Rights, it was said: "All human rights are universal, indivisible, interdependent and interconnected" [15,22]. This, in principle, testifies to the comprehensive nature of this right. In other words, self-determination cannot be reduced solely to political aspects and forms, but it must certainly encompass many components, such as the right to life and independent existence, conducting traditional housekeeping, and respect for a unique worldview.

This characteristic can also be expressed in the fact that the right to self-determination applies not only to political status but also equally implies economic, social and cultural development. According to R. McCorkodale, it forms "a complex of closely intertwined and inextricably linked related rights that are interdependent so that not one aspect is of paramount importance to any other" $[16, \mathrm{p} .8,9]$.

Accordingly, it is assumed that the key elements of the right to self-determination are still land and natural resources. Indeed, a number of authors, including a well-known American politician representing the Cree people, Ted Moses, emphasized: the most obvious problem of indigenous peoples is "their inability to live and manage on their own lands, including the ability to use their resources necessary to maintain their life and development" $[17,21]$. And given that indigenous peoples, in principle, do not represent life outside their ancestral lands, any obstacle or denial of their rights, including the right to livelihood from "those who began to live on their land" in the present time, constitutes one of the most flagrant violations of the right to self-determination. Such a right, in accordance with the meaning of paragraph 2 of Article 1 common to both Covenants [18,19-20], as well as with Article 25 of the ICESCR and Article 47 of the ICCPR, is recognized as the embodiment of the very essence of life. In other words, the main meaning of the right of indigenous peoples to self-determination is the ability to have and realize their conscious choice in relation to themselves and their lifestyle.

\section{CONCLUSIONS}

Thus, in conclusion of the analysis of such a complex phenomenon as the right of indigenous peoples to self-determination, we want to say that this right is the basis of all the rights of these ethnic communities, but also the basis of their existence in this world.

In accordance with this, it seems to us possible to note that the right of indigenous peoples to self-determination today must certainly be considered much broader than the definitions that exist in practice and in theory, which reduce the latter to independence, the right to autonomy or self-government. It must certainly imply real measures to correct the existing violations of the rights of these ethnic communities, as well as imply freedom of action regarding lifestyle and guarantee its implementation at the national and international levels.

\section{REFERENCES}

1. Morris G. T. In Support of the Right of Self-Determination for Indigenous Peoples under International Law. German Yearbook of International Law. Vol. 29. Berlin, 1986.

2. Nettheim G. Peoples and Populations - Indigenous peoples and the Rights of Peoples. The Rights of Peoples. Ed. by James Crawford Oxford: Clarendon Press, 1988.

3. United Nations Declaration on the Rights of Indigenous Peoples. Adopted by General Assembly resolution 61/295 dated September 13, 2007 [Electronic resource] // URL: https://www.un.org/en/documents/decl_conv/declarations/indigenous _rights.shtml. (Access date: 1 June 4, 2019).

4. Kingsbury B. Reconciling Five Competing Conceptual Structures of Indigenous Peoples' Claims in International and Comparative Law in Philip Alston (ed). Peoples' Rights. New York: Oxford University Press, 2001

5. Corntassel J. J., Primeau T. H. Indigenous 'Sovereignty' and International Law: Revised Strategies for Pursuing ‘Self-Determination'. Human Rights Quarterly. Vol. 17. № 2. 1995.

6. Anaya J. S. Indigenous Peoples in International Law. Sec. ed. Oxford University Press, 2000.

7. Garipov R.Sh. Protection of indigenous peoples in international law.Monograph. Kazan: Center for Innovative Technologies, 2012.

8. Nuttall M. Self-Rule in Greenland: Towards the World's First Inuit State? Indigenous Affairs. Vol. 3-4. 2008.

9. This regulation is reflected in Cl.1 of Additional Protocol I dated 1977; The UN Charter and the Declaration of Principles of International Law Relating Friendly Relations and Cooperation between States in accordance with the 1970 UN Charter.

10. Ananidze F. R. International legal problems of the protection of the rights of indigenous peoples. Thesis for the degree of candidate of legal sciences. Moscow. 1996 